\title{
Artikkeli
}

\section{Strateginen viestintä ja organisaation tavoitteet Mihin viestinnällä pyritään?}

Strateginen viestintä on 2000-luvun viestinnän tutkimuksessa noussut PR:n, yhteisöviestinnän, viestinnän johtamisen ja integroidun viestinnän rinnalle sekä osittain korvaamaan niitä. Tässä artikkelissa tarkastelemme, miten organisaatiot määrittelevät viestinnän tavoitteitaan ja millaisia strategisen viestinnän näkemyksiä ne kuvastavat. Tarkastelemme kysymystä sekä tutkimuskirjallisuuden että empiirisen aineiston valossa. Erittelemme tutkimuskirjallisuuden käsityksiä strategisen viestinnän käsitteestä ja sen kytköksestä organisaation tavoitteisiin sekä strategisen viestinnän ongelmista. Empiirisen aineiston osalta tutkimme, miten organisaatiot itse määrittelevät viestintänsä tavoitteet ja mikä viestinnän tavoitteiden suhde on organisaation strategiaan ja strategisiin tavoitteisiin.

AVAINSANAT: organisaatioviestintä, strategia, strateginen viestintä, viestintästrategia, viestinnän tavoitteet, viestinnän kontribuutio

S trategisuus tai tavoitteellisuus on ollut viestintäalan pitkäaikainen keskustelunaihe. 2010-luvulla strateginen viestintä on noussut tutkimuksessa osittain korvaamaan PR:n (public relations), yhteisöviestinnän, viestinnän johtamisen ja integroidun viestinnän käsitteitä tai ainakin niiden vaihtoehdoksi (Zerfass ym. 2018)'. Viimeaikaisessa tutkimuksessa viestinnällä on esitetty olevan keskeinen strateginen rooli organisaatiossa. Yhtäältä viestintä kytkeytyy organisaation strategisiin tavoitteisiin. Toisaalta organisaatioiden nähdään rakentuvan ja olevan olemassa ihmisten välisen vuorovaikutuksen ansiosta. Laajimmillaan "strategisena" on pidetty kaikkea organisaation kannalta elintärkeää viestintää. (Hallahan ym. 2007; Holtzhausen \& Zerfass 2015; Zerfass ym. 2018, van Ruler 2018.) Strategista viestintää on tarkasteltu myös omana viestinnän ja sen tutkimuksen paradigmanaan, joka pyrkii integroimaan viestinnän osa-alueita ${ }^{2}$ yhteisen sateenvarjon alle ja kattamaan kaikenlaiset organisaatiot ja yksittäiset henkilövaikuttajat ${ }^{3}$ (emt). 
Strategisen viestinnän asema itsenäisenä paradigmana on myös kyseenalaistettu, ja strategista viestintää on käsitelty pikemminkin yhtenä viestintätieteiden kehittyvänä alalajina (van Ruler 2018; Lock ym. 2020). Strategisen viestinnän tutkimusta on kritisoitu monin tavoin, ja se on liitetty managerialismiin ja positivismiin (Alvesson \& Sveningsson 2011; Holtzhausen \& Zerfass 2013, 284; Holtzhausen \& Zerfass 2015; Torp 2015, 34-52; Werder ym. 2018). Strategisen lähestymistavan on ajateltu alistavan kaikki viestinnän muodot organisaation strategisten tavoitteiden saavuttamiselle. Tutkimuksessa tämän on esitetty sekä metodologisesti että tutkimuskysymyksiltään peittävän alleen tutkittavan kohteen - organisaatioiden viestinnän - moninaisuuden.

Tavoitteemme on tarkastella organisaatioiden viestinnän tavoitteita ja lisätä ymmärrystä viime aikoina yleistynyttä strategisen viestinnän käsitettä kohtaan. Emme lähde liikkeelle tietystä strategisen viestinnän käsitteestä vaan siitä esiymmärryksestä, että strategista viestintää (tai viestinnän strategisuutta) määrittää viestinnän (tiivis tai löyhä) suhde organisaation strategiaan ja sen toteuttamiseen. Strategisen (tai sellaiseksi kutsutun) viestintäajattelun yleistyessä pyrimme ensisijaisesti osallistumaan keskusteluun selkeyttämällä sitä, mitä strategisuus viestinnässä merkitsee.

Tarkastelemme ensin tutkimuskirjallisuudessa esiintyviä käsityksiä strategisesta viestinnästä ja sen kytköksestä organisaation strategisiin tavoitteisiin. Käsittelemme myös strategiseen viestintään suunnattua kritiikkiä. Artikkelin toinen osio sisältää empiirisen aineiston analyysin ja tulokset. Aineisto koostuu kolmen viestinnän koulutusohjelman osallistujille suunnatusta kyselystä. Aineiston osalta kysymme, millaista kontribuutiota organisaatiot odottavat viestinnältä, millaisia tavoitteita asetetaan ja millä tavoin viestinnän ja organisaation strategia kytkeytyvät toisiinsa. Lopuksi peilaamme tuloksia aiempaan tutkimukseen.

\section{Viestinnän strateginen käänne}

Strateginen viestintä pohjaa strategian ja strategisen johtamisen käsitteistöön. Viestintä liitetään organisaation strategisiin prosesseihin eli strategian määrittelyyn ja arviointiin, esittelyyn, toteutukseen ja uudelleen arviointiin sekä kommunikointiin julkisuuden areenoilla (Holtzhausen \& Zerfass 2013, 283-302; Zerfass ym. 2018; van Ruler 2018). Strategian käsite on peräisin kreikan kielen sanasta бтратпүó (sotapäällikkö). Saksalaista sodankäynnin teoreetikkoa Carl von Clausewitzia (1780-1831) on pidetty strategian "ylipappina", jonka oppeja on laajasti omaksuttu liike-elämään. Viestinnän piirissä Clausewitzin sanomaa on vieroksuttu dikotomisen voita tai häviä -asetelman vuoksi (Nothhaft \& Schölzel 2015, 18-33).

Jo ennen strategisen viestinnän käsitteen syntyä strategisuus on ollut PR-alan keskustelunaihe 1950-luvulta lähtien (mm. Bernays 1952). Ajatus PR:stä tavoitteellisena toimintana on kirjattu PR-ammattilaisten työtä ohjaaviin dokumentteihin vuoden 1978 Meksikon julistuksesta lähtien. Tästä huolimatta tutkijat pitkään näkivät vies- 
tinnän pääasiassa taktisena ja operatiivisena, organisaation ydintoiminnoista irrallaan olevana funktiona (Moss \& Warnaby 1998).

2000-luvulla voidaan puhua viestinnän strategisesta käänteestä. Viestinnästä on tullut yhä tavoitteellisempaa ja se on muodostunut osaksi organisaatioiden johtamista. Simon Møberg Torpin (2015, 34-52) mukaan tähän on vaikuttanut se, että organisaatioiden viestintä on ylittänyt perinteiset organisaatiorajat ja laajentunut koskemaan kaikkea organisaation toimintaa ja viestintää sekä kaikkia viestinnän osapuolia. Strateginen käänne merkitsee viestinnän ymmärtämistä kaksoisfunktion kautta: sekä pyrkimyksenä tehokkuuteen ja vaikuttavuuteen että haluna osallistaa henkilöstöä ja sidosryhmiä erilaisilla julkisuuden areenoilla (Holtzhausen \& Zerfass 2015, 3-17). Organisaatiot käsitetään yhteiskunnallisina toimijoina, jolloin kaikki viestintä on periaatteessa julkista. Tällöin viestintä muokkautuu sidosryhmiä ja yleisöjä osallistavaan suuntaan sen sijaan että esitetään yksisuuntaisesti omia näkemyksiä (Bentele \& Nothhaft 2010). 2000-luvulla strateginen viestintä on levinnyt kaikille yhteiskunnan alueille, ja sitä käytetään usein synonyymina yhteisö- ja yritysviestinnälle, viestinnän johtamiselle ja integroidulle viestinnälle. Viestinnän rooli organisaation strategiaprosesseissa on vahvistunut, kun strategian luominen ja toteutus on alettu nähdä eri osapuolten välisenä dialogina (Barge \& Little 2002; Deetz 2006; Fairhurst \& Connaughton 2014; van Ruler 2018).

\section{Strategisen viestinnän 'paradigma'}

Strategista viestintää on kutsuttu uudeksi, nousevaksi tutkimusparadigmaksi (Hallahan ym. 2007; Werder ym. 2018), ja sitä on pidetty selvästi erilaisena lähestymisenä organisaatioiden viestintään verrattuna aiempiin viestinnän lajityyppeihin (Holtzhausen \& Zerfass 2015). Strategisen viestinnän käsitettä on käytetty myös PR:iin liittyvien negatiivisten konnotaatioiden välttämiseksi (Hallahan ym. 2007; Zerfass ym. 2018).

Hallahan, Holtzhausen, van Ruler, Verčič ja Sriramesh (2007) määrittelivät strategisen viestinnän viestinnäksi, joka tarkoituksellisesti (purposeful) täyttää tai tukee organisaation mission toteutumista ja vaikuttaa tärkeiden tavoitteiden saavuttamiseen. Zerfass, Verčič, Nothhaft ja Werder (2018) laajentavat määritelmän kattamaan kaiken viestinnän - ei ainoastaan tarkoituksellisen - joka on oleellista ja elintärkeää organisaation olemassaololle ja menestykselle ja joka tukee organisaation päätöksentekoa. Tämä laajentaa strategisen viestinnän myös julkisuuden areenoille, joilla organisaatiota koskevia tai sivuavia asioita käsitellään. Läsnäolo ja osallistuminen rajataan organisaation tavoitteiden kannalta oleellisiin julkisuuksiin. Määritelmän ulkopuolelle jäävät viestinnän rutiinit ja taktiset operaatiot, jotka voivat silti olla tarpeellisia.(Emt.)

Strategisen viestinnän paradigmassa viestinnän nähdään kiinnittyvän organisaation strategisiin tavoitteisiin, riskien- ja maineenhallintaan sekä yhteiskuntavastuuseen (Holtzhausen \& Zerfass 2013, 283-302). Riippumatta organisaation luonteesta, strategisessa viestinnässä keskeisiä ovat sidosryhmien ja yleisöjen tunnistaminen ja segmentointi, mediat ja julkisuus, viestinnän tulokset, maineenhallinta ja viestintäammattilaisten roolit (Holtzhausen \& Zerfass 2015). 


\section{Funktionalistinen ja konstitutiivinen lähestyminen}

Organisaatioviestinnän funktionalistinen perinne käsittää viestinnän prosessina, joka palvelee organisaation tavoitteita ja saa aikaan haluttuja muutoksia välittämällä informaatiota sekä sitouttamalla henkilöstöä ja sidosryhmiä tavoitteiden toteuttamiseen (Shockely-Zalabak 2012, 30-31). PR:n ja yhteisöviestinnän tutkimuksessa viestintä määritellään johtamisfunktioksi, jonka tehtävänä on rakentaa suhteita strategisiin sidosryhmiin ja palvella organisaation (pää)strategiaa sekä antaa suunnan viestinnän operatiiviselle toiminnalle (Grunig \& Hunt 1984; Steyn 2004; Cornelissen ym. 2006; Raupp \& Hoffjann 2012; Cornelissen 2014; Mykkänen 2018, 326).

Strategiselle viestinnälle voidaan samanlaisista lähtökohdista antaa rajatun funktionalistinen määritelmä, jossa viestintä on alisteinen organisaation strategialle ja palvelee sitä (Botan 2006, 223-247; Raupp \& Hoffjann 2012; Steyn \& Niemann 2014). Viestintä on strategista, kun ja koska sillä on keskeinen rooli organisaation (strategisten) tavoitteiden saavuttamisessa ja organisaation johtamisessa. Tässä organisaation strategiaan peilaavalla viestinnän suunnittelulla on keskeinen rooli; viestintä nähdään usein johdon työkaluna (mm. Åberg 2000; Bigler 2004; Christensen 2014), ja viestinnän tavoitteet ja strategia johdetaan suoraan organisaation strategiasta (Volk ym. 2017).

Strategista viestintää koskevassa tutkimuskeskustelussa on toisaalta tuotu esiin myös viestinnän perustavanlaatuista merkitystä koko organisaation muodostumiselle ja jatkuvuudelle. Tutkimuksessa tämä lähestymistapa tunnetaan nimellä Communication as Constitutive of Organizing/Organization CCO (Taylor \& Van Every 2000; Taylor 2009, 153-186; Cooren ym. 2011; Putnam \& Nicotera 2010; Vásquez \& Schoeneborn 2017). Van Ruler (2018) on esittänyt strategia- ja viestintäajattelun yhdistämistä siten, että viestintä ymmärretään jatkuvina prosesseina, joissa strategiaa rakennetaan, määritellään, toteutetaan, arvioidaan ja määritellään yhä uudelleen koko organisaation voimin. Strateginen viestintä käsitetään tällöin organisaation läpileikkaavana ilmiönä: sekä organisaatio itse että sen strategia rakentuvat ja uusiutuvat inmisten välisessä vuorovaikutuksessa (Cooren ym. 2011; Kuhn \& Schoeneborn 2015; Heide ym. 2018). Tästä konstitutiivisesta näkökulmasta, kuten sitä tässä nimitämme, strateginen viestintä on organisaation ja sen tavoitteiden muodostamista viestinnän keinoin pikemminkin kuin strategisten tavoitteiden saavuttamista viestinnän keinoin.

\section{Deliberatiivinen ja emergentti strategia-ajattelu}

Liikkeenjohdon klassisen suunnittelukoulukunnan (Ansoff 1965; Steiner 1969; Steiner 1979; Wright, Lorange 1980; Pringle \& Kroll 1992) mukaan strategia näyttää organisaation suunnan, auttaa fokusoimaan toimintaa, vahvistaa itseymmärrystä ja mahdollistaa johdonmukaisen toiminnan. Strategioita on tutkimuksessa jaoteltu kahteen tyyppiin: deliberatiivisiin strategioihin, jotka ovat tavoitteellisia (intended) ja jotka joko toteutuvat tai eivät toteudu, sekä emergentteihin strategioihin, joissa tavoitteet saavutetaan 
toisin kuin oli suunniteltu tai erilaisina suunnittelun ja sattuman yhdistelminä (Mintzberg ym. 2009). Emergentin strategia-ajattelun mukaan strategiat muovautuvat ja toteutuvat vuorovaikutuksessa ja merkityksenantojen kautta (Kent \& Taylor 2002; Fairhurst \& Connaughton 2014; Fairhurst \& Uhl-Bien 2012) ja organisaation arjessa (Johnson ym. 2003; Jarzabkowski 2004; Jarzabkowski 2005; Jarzabkowski ym. 2007).

Viestinnän rooli organisaatiossa voidaan käsittää deliberatiivisen strategiaotteen mukaisesti: viestinnän lopulliseksi tavoitteeksi asetetaan kontribuutio organisaation tavoitteiden saavuttamiseen, usein rajatummin kilpailu- tai muun edun tuottaminen organisaatiolle (Steyn 2004; Ströh 2007, 199-220; Raupp \& Hoffjann 2012; Steyn \& Niemann 2014). Deliberatiivisen ja suunnittelua korostavan strategia-ajattelun on arvioitu dominoivan strategisen viestinnän tutkimusta ja myötäilevän managerialistista lähestymistä (Holtzhausen \& Zerfass 2013, 284). Deliberatiivinen strategia-ajattelu yhdistyy näin usein funktionalistiseen käsitykseen strategisesta viestinnästä.

Toisaalta perinteisen johdon strategiatyön ja strategisen johtamisen tilalle on ehdotettu konstitutiivisen viestinnän näkökulmaa, jossa organisaation strategiat muovautuvat viestinnän keinoin (Heide ym. 2018; van Ruler 2018). Tämä lähestyminen liittyy pikemminkin emergenttiin strategiaotteeseen. Edellä esitelty strategisen viestinnän paradigma puolestaan laajuudessaan voi kattaa molempia strategiaotteita. Tutkimuskirjallisuus tarjoaa näin kolme jossakin määrin toisistaan poikkeavaa strategisen viestinnän käsitettä tai näkemystä (ks. Taulukko 1).

Taulukko 1. Kolme lähestymistä strategiseen viestintään.

\begin{tabular}{|l|l|l|l|}
\hline & $\begin{array}{l}\text { Taustalla } \\
\text { oleva } \\
\text { strategia- } \\
\text { ajattelu }\end{array}$ & Strategisen viestinnän luonne & Tutkijoita \\
\hline $\begin{array}{l}\text { Strategisen } \\
\text { viestinnän } \\
\text { 'paradigma' }\end{array}$ & $\begin{array}{l}\text { Deliberatiivi- } \\
\text { nen / } \\
\text { emergentti }\end{array}$ & $\begin{array}{l}\text { Organisaatiolle elintärkeä viestintä, } \\
\text { joka tukee päätöksentekoa, } \\
\text { strategisia prosesseja ja } \\
\text { tavoitteiden saavuttamista - myös } \\
\text { rajallinen osallistuminen dialogiin } \\
\text { tarkoituksenmukaisella tavalla }\end{array}$ & $\begin{array}{l}\text { Hallahan ym. 2007; } \\
\text { Hallahan 2015; Nothhaft } \\
\text { 2016; Heide ym. 2018; } \\
\text { Botan 2018; Nothhaft ym. } \\
\text { 2018; Van Ruler 2018 }\end{array}$ \\
\hline $\begin{array}{l}\text { Funktio- } \\
\text { nalistinen }\end{array}$ & $\begin{array}{l}\text { Delibera- } \\
\text { tiivinen }\end{array}$ & $\begin{array}{l}\text { Viestintä johtamisfunktiona } \\
\text { organisaatiostrategian } \\
\text { toteuttamisessa sekä viestinnän } \\
\text { strategisten tavoitteiden } \\
\text { määrittelyssä ja johtamisessa }\end{array}$ & $\begin{array}{l}\text { Arberg 2000; Steyn 2004; } \\
\text { Argenti ym. 2005; } \text { Ströh } \\
\text { 2007; Cornelissen 2014; } \\
\text { Christensen 2014; Steyn \& } \\
\text { Niemann 2014 }\end{array}$ \\
\hline $\begin{array}{l}\text { Konstitu- } \\
\text { tiivinen }\end{array}$ & Emergentti & $\begin{array}{l}\text { Viestinnän perustavanlaatuinen } \\
\text { rooli organisaation rakentumisessa } \\
\text { ja ylläpidossa, strategian } \\
\text { muodostamisessa, toteutumisessa } \\
\text { ja jatkuvassa arvioinnissa } \\
\text { vuorovaikutteisina prosesseina }\end{array}$ & $\begin{array}{l}\text { Taylor \& Van Every, 2000; } \\
\text { Cooren ym. 2011; Vásquez } \\
\text { \& Schoeneborn 2017; } \\
\text { van Ruler 2018; } \\
\text { Putnam \& Nicotera 2010; } \\
\text { Kuhn \& Schoeneborn 2015 }\end{array}$ \\
\hline
\end{tabular}


Näkökulmat eivät ole toisensa poissulkevia; pikemminkin tutkimuskirjallisuudessa ne usein yhdistyvät. Strategisella viestinnällä voidaan yhtä aikaa tarkoittaa viestinnän roolia sekä strategisten tavoitteiden saavuttamisessa että strategian - ja organisaation - muodostamisessa (esim. van Ruler 2018). Edelleen nämä voidaan käsittää organisaatiolle elintärkeäksi viestinnäksi.

\section{Strategisen viestinnän kritiikki}

Strategisen viestinnän kritiikki voidaan karkeasti jakaa kolmeen alalajiin. Ensimmäinen kohdistuu funktionalistiseen lähestymiseen, jossa strategisuus tarkoittaa viestinnän valjastamista organisaation edun ajamiseen. Tämä lähestyminen on tutkimuksessa yhdistetty suostutteluun ja manipulaatioon (Holtzhausen \& Zerfass 2015). Tällainen kritiikki esiintyy erityisesti silloin, kun viestintä ymmärretään pelkästään yksisuuntaisena, organisaatiokeskeisenä vaikuttamisena (Heide ym. 2018; Zerfass ym. 2018).

Toisen kritiikin mukaan strategisella viestinnällä on taipumus suosia johdon intressejä, ja se on luonteeltaan puolueellista ja subjektiivista (Heide ym. 2018; Nothhaft 2016). Strategiseen viestintään on yhdistetty vallan ja kontrollia painottavan johtamisen sekä organisaatiokeskeisyyden ongelmia (Hallahan ym. 2007; Nothhaft 2015, 18-33; Zerfass ym. 2018). Sitä on myös kritisoitu toimintaympäristön moninaisuuden ja kompleksisuuden jättämisestä huomiotta (O'Connor \& Shumate 2018) sekä haluttomuudesta tunnustaa, että organisaatiot voivat toimia epärationaalisesti (Heide ym. 2018). Myös vaihtoehtoisten strategianäkemysten, kuten esimerkiksi emergentin strategiakäsityksen ja viestinnän konstitutiivisen luonteen huomiotta jättämistä on pidetty puutteena (Zerfass ym. 2018; Heide ym. 2018).

Kolmas kriittinen näkökulma kohdistuu strategisen viestinnän tutkimukseen, jota dominoi management-perinne (Werder ym. 2018). Positivismista ja managerialismista omaksutun lähestymisen on arvioitu peittävän alleen viestinnän tutkimuksen edellyttämän teoreettisen ja metodologisen pluralismin (Nothhaft 2016; Heide ym. 2018; van Ruler 2018). Strategista viestintää ei myöskään pidetä selkeästi erottuvana tutkimusalueena eikä paradigmana (Zerfass ym. 2018) vaan yhtenä viestinnän tutkimuksena alalajina, jolta puuttuu yhtenäinen teoriapohja (Nothhaft 2016; Lock ym. 2020). Yhtenäisten teoreettisten lähtökohtien puuttuessa puhe "paradigmasta" voi olla liioiteltua. Strategisen viestinnän tutkimuksen tavoittelema monitieteisyys voi olla liian suuri haaste, kun viestintäteoreettinen pohjakin on vielä ohut (Nothhaft 2016; Heide ym. 2018; Lock ym. 2020).

Viestinnän osa-alueiden integrointi strategisen viestinnän paradigman alle voi kriitikoiden mielestä johtaa viestinnän ilmiöiden tarkasteluun liian kapeasta näkökulmasta. Tällaisen näkemyksen tutkimuksen rajoittautuneisuudesta tarjoaa International Journal of Strategic Communication -lehden artikkelien (2007-2017) sisällönanalyysi (Werder ym. 2018), jonka mukaan strategisen viestinnän ymmärrys edustaa voittopuolisesti positivismia ja managerialismia, vaikka aito integrointi vaatisi vakiintuneiden tieteenalojen rohkeaa ylittämistä ja innovatiivisempia tutkimusaiheita ja -metodeja (O'Connor \& Shumate 2018; Heide ym. 2018). 
Strategisen viestinnän kritiikki on kiinnostavassa suhteessa konstitutiiviseen näkemykseen, joka korostaa moniäänisen viestinnän asemaa kaikessa organisaatioelämässä ja strategian muodostumista ilman etukäteen määrättyä lopputulosta (van Ruler 2018; van Ruler \& Körver 2019). Sekä kritiikki että konstitutiivinen näkemys strategisesta viestinnästä perustuvat ajatukseen viestinnästä sosiaalisen todellisuuden rakentajana. Edelleen strategisen viestinnän kritiikki näyttää kohdistuvan pääosin funktionalistiseen näkemykseen viestinnästä organisaation tavoitteiden palvelijana. Se ei pure yhtä terävästi, mikäli viestinnän tavoitteet käsitetään laajemmin kuin pelkästään organisaatiolle tuotettavana etuna. Kritiikin osuvuus riippuu näin tapauskohtaisesti strategian määrittelystä ja tulkinnasta sekä viestinnän yhteydestä strategisiin tavoitteisiin. Tämän vuoksi erityistä huomiota on kiinnitettävä strategisen viestinnän ja organisaation tavoitteiden väliseen suhteeseen.

\section{Viestinnän tavoitteiden määrittelyä}

Tutkimuksessa strategisen viestinnän suhdetta organisaation strategiaan on lähestytty eri tavoin. Funktionalismin hengessä viestintää on tarkasteltu alisteisena organisaation strategialle (ks. Steyn 2004; Botan 2006, 223-247; Raupp \& Hoffjann 2012). Viestinnän strategisuus on myös käsitetty organisaation erillisen viestintästrategian ja organisaation strategian yhteytenä. Organisaatio- ja viestintästrategioiden on strategisessa viestinnässä ajateltu kietoutuvan toisiinsa (Cornelissen 2014; Zerfass ym. 2017) tai viestinnän on ajateltu liittyvän löyhemmin organisaatiostrategiaan (van Ruler \& Körver 2019). Viimeksi mainitussa viestintästrategia nähdään väljänä kehyksenä, joka mahdollistaa jatkuvan adaptoitumisen muuttuviin olosuhteisiin. Organisaatiostrategia kyllä huomioidaan, mutta sen ei anneta kahlita "älykästä pragmatismia ja joustavuutta". (Emt.)

Viestinnän strategisuutta onkin mahdollista lähestyä tarkastelemalla viestintästrategian ja organisaation strategian - erityisesti sen sisältämien tavoitteiden välistä suhdetta. Yleisesti viestintästrategia on organisaation muodostama yhteinen näkemys siitä, miten viestintä kontribuoi organisaation menestykseen ja tavoitteiden saavuttamiseen sekä lisäarvon tuottamiseen. Sen tehtävänä on auttaa tekemään valintoja, joilla on merkitystä ja vaikuttavuutta (Volk ym. 2017; van Ruler \& Körver 2019).

Viestintästrategian keskeistä sisältöä ovat eri termein ilmaistut viestinnän tavoitteet, jotka ilmentävät viestinnän ja organisaatiostrategian suhdetta. Kirk Hallahanin (2015, 244-266) mukaan modernismia edustavan tavoitejohtamisen (managementby-objectives) periaatteet ovat juurtuneet myös viestintäajatteluun, mikä näkyy usein suoraviivaisena funktionalismina. Hallahan erottelee toisistaan organisaation päämäärät (esimerkiksi myynti, tuotot, tulos, vaikutusvalta) ja viestinnän tavoitteet, jotka hän jakaa vaikuttamisekseen valintoihin (esimerkiksi ostaa, äänestää) sekä niitä edeltäviin välitavoitteisiin, kuten esimerkiksi vaikuttamista tietoihin, asenteisiin, tiedon etsintään ja jakamiseen. 
Toinen tapa on jakaa tavoitteita viestinnän tehtäviin. Tällaisia ovat esimerkiksi henkilöstön informointi ja motivointi, luottamuksen rakentaminen, imago, informointi tai yritysstrategian ymmärrys, joiden odotetaan tuottavan viestinnän kontribuutiota organisaatiolle strategian toteutumiseen, liiketoiminnan tehostumiseen tai tulevaisuuteen varautumiseen (Zerfass \& Sherzada 2015).

Tavoitteita voidaan esittää aineettomien ja aineellisten tulosten näkökulmasta. Aineettomia ovat esimerkiksi maine, brändi, legitimiteetti, sidosryhmien tai yleisöjen luottamus (Luoma-aho ym. 2012; Carroll 2013, 590-596; Cornelissen 2014; Gregory ym. 2013, 268-283; Zerfass \& Sherzada 2015), motivointi toivottuun muutokseen (Cornelissen 2017; Pratt \& Hu 2017) tai yhteiskunnan hyväksyntä (Steyn 2003). Myös vastuullisuus ja eettisyys, jopa yleinen hyvä voivat olla viestintästrategiassa esitettyjä tavoitteita (Steyn 2003; van Ruler \& Körver 2019).

Aineellisiksi tulosten voidaan ajatella muuttuvan, kun niillä on mitattavaa lisäarvoa: tuottavuutta, laatua tai tehokkuutta esimerkiksi työpoissaolojen vähentymisenä (Desmidt \& George 2016). Nämä ovat usein välineitä organisaation taloudellisiin tavoitteisiin, kuten esimerkiksi myyntiin, markkinaosuuteen, säästöihin tai muuhun vaikuttavuuteen (Zerfass \& Sherzada 2015; Zerfass \& Viertmann 2017).

Viestinnän tavoitteet voidaan esittää myös organisaation itsensä näkökulmasta. Taustalla voi olla edellä esitelty konstitutiivisen viestinnän ajatus, että organisaatiot rakentuvat ja niitä ylläpidetään ihmisten välisessä vuorovaikutuksessa ja viestinnässä (ks. Putnam \& Nicotera 2010). Organisaation näkökulmasta tavoitteena voi olla toiminnan jatkuvuus ja legitimointi, organisaation uusiutuminen ja reflektiivisyys (Schön 1983; Holmström 2005; Holmström 2007).

Kaikki edellä mainitut tavoitteet edustavat kontribuutioita organisaation tavoittelemien tulosten saavuttamiseksi tai organisaation itsensä olemassaololle. Toisaalta tavoitteet voivat koskea viestintää itsessään ilman selvästi ilmaistua kytköstä organisaation tavoitteisiin. Nämä voivat näyttäytyä esimerkiksi viestinnän periaatteiden, arvojen tai etiikan sisällyttämisenä viestinnän tavoitteisiin (Fawkes 2007; Bowen 2016). Myös itse viestintä sekä yhteisöllisyyden ja vuorovaikutuksen rakentaminen voivat sellaisenaan olla tavoitteita, samoin kuin tunnettuus, näkyvyys, maine tai brändi päämäärinä itsessään.

Koska strateginen viestintä katsoo organisaatioksi yritysten ja yhteisöjen lisäksi myös henkilötoimijoita ja -vaikuttajia (Zerfass ym. 2018), tavoitteet voivat olla hyvin erilaisia. Yritysten intressinä on osakkeenomistajien etu, vaikka monet pyrkivät proaktiivisesti osoittamaan vastuullisuutensa taloudellisten tavoitteiden ja yhteiskunnallisen hyväksyttävyyden välillä (Olkkonen 2015; Luoma-aho \& Olkkonen 2016, 303-306; Lock \& Schulz-Knappe 2019). Julkiset organisaatiot ovat tilivelvollisia useille tahoille: osallisuus on yksi perusarvoista (Asunta \& Mikkola 2019, 72-87) ja viestinnältä vaaditaan läpinäkyvyyttä (Canel \& Luoma-aho 2019. Reunaehtoja kaikille organisaatioille tuovat paikallinen tai globaali lainsäädäntö ja monenlaiset säädökset.

Seuraavassa osiossa tarkastelemme organisaatioiden itsensä määrittelemiä tavoitteita viestinnälle näiden jaotteluiden valossa. 


\section{Aineistot ja analyysi}

Tässä osiossa käsittelemme empiirisen aineiston valossa organisaation viestinnälle asettamia tavoitteita sekä näiden suhdetta organisaation strategisiin tavoitteisiin. Etsimme aineistosta vastauksia seuraaviin kysymyksiin:

1. Millaisia tavoitteita organisaatiot asettavat viestinnälle?

2. Mitä johtajat/esimiehet ja viestintäammattilaiset odottavat viestinnältä organisaation tavoitteiden edistämiseksi (kontribuutio)?

3. Millä tavoin viestinnän tavoitteet suhteutuvat organisaation strategiaan, missioon tai muuhun julkilausumaan?

Aineisto koostuu kaupallisen koulutusyrityksen vuosina 2018, 2019 ja 2020 pidettyjen viestintäpäällikkökurssien osallistujien vastauksista. Aineiston kokosi koulutusyhtiö kurssin omalla verkkoalustalla, ja tämän artikkelin kirjoittajilla oli pääsy aineistoon. Aineiston käyttöön pyydettiin lupa osallistujilta².

Taulukko 2. Empiirinen aineisto.

\begin{tabular}{|l|l|l|l|l|}
\hline & $\begin{array}{l}\text { Osallistujien } \\
\text { organisaatiot }(\mathrm{N})\end{array}$ & $\begin{array}{l}\text { Tutkimusluvan } \\
\text { antaneet }(\mathrm{N})\end{array}$ & $\begin{array}{l}\text { Johtajat/ } \\
\text { esimiehet }(\mathrm{N})\end{array}$ & Viestijät (N) \\
\hline 2018 & 14 & $13^{\star}$ & 10 & 13 \\
\hline 2019 & 23 & $19^{\star *}$ & 10 & 19 \\
\hline 2020 & 24 & $21^{\star * *}$ & 17 & 21 \\
\hline yhteensä & 61 & 53 & 37 & 53 \\
\hline
\end{tabular}

*) 6 yritystä, 4 julkishallintoa, 3 järjestöä/säätiötä

**) 7 yritystä, 9 julkishallintoa, 3 järjestöä/säätiötä

***) 10 yritystä, 8 julkishallintoa, 3 järjestöä/säätiötä

Osallistujille jaettiin seuraavat kysymykset kurssin verkkoalustalla, jossa he vastasivat omilla nimillään mutta eivät nähneet toistensa vastauksia:

1) Haastattele esimiestäsi, mielellään ylintä johtoa, ja kysy a) mitkä ovat hänen odotuksensa koskien viestinnän vaikuttavuutta ja b) millaisin mittarein tai miten hän arvioi viestinnän vaikuttavuutta?

2) Kerro lyhyesti organisaationne $2-4$ viestinnän strategista tavoitetta.

Aineistonkeruumenetelmänä oli teemakirjoittaminen, jossa tutkija esittää kysymykset, joihin osallistujat vastaavat kirjoittaen (ks. Apo 1995; Hirsjärvi \& Hurme 2008, 34-35).

Esimiesten vastaukset olivat tyypillisesti noin $1 / 2-1$ sivun laajuisia. Vastaukset olivat paikoin hyvin yleisiä abstrakteja ja etenivät loogisesti. Viestijöiden vastaukset olivat monivivahteisempia, konkreettisempia ja laajuudeltaan 1-3 sivun mittaisia. 


\section{Menetelmät}

Tutkimusstrategiaksi valikoitui laadullinen ote, jolla pyritään ymmärtämään tutkittavaa ilmiötä ja saamaan siitä syvempi käsitys kuin teoriapohjaisilla monivalintakysymyksillä. Kiinnostus kohdistuu tietämisen sisältöön ja vastaajien luomiin merkityksiin perusteltuina faktoina, joita käytetään apuna tutkittaessa todellisuuden rakentumista (Alasuutari 2001; Tuomi \& Sarajärvi 2002, 58). Laadullinen tutkimus on yleensä hypoteesiton, ja siinä edetään aineistosta käsin ilman selkeitä ennakko-oletuksia (Eskola \& Suoranta 2000, 19-20). Keskeistä on ilmiön paikallinen selittäminen universaalien lainalaisuuksien tai yleistysten sijaan (Alasuutari 1999).

Määrällisiä huomioita esitämme, kun jokin asia tulee vastaan toistuvasti tai jos jokin asia ei esiinny lainkaan tai hyvin harvoin. Analyysimme on luonteeltaan teoriasidonnaista, jolloin analyysissa on teoreettisia kytkentöjä, mutta se ei suoraan nouse teoriasta tai pohjaudu teoriaan (Eskola 2018, 209-231). Toisaalta olemme avoimia huomioimaan asioita, joita ei ole tunnistettu aiemmassa tutkimuksessa.

Laadullinen analyysi muodostuu usein kolmesta vaiheesta: aineiston redusointi, klusterointi ja abstrahointi. Hyödynsimme analyysissamme teemoittelua, jossa aineistosta poimitaan tutkimusongelmaa valaisevia avainsanoja tai lausumia; selontekoja, jotka on tarkoitettu ohjeistamaan tai perustelemaan valintoja. Teemoittelua voidaan viedä pidemmälle kohti tyypittelyä, jolloin aineistoa ryhmitellään samankaltaisuuksien avulla kattavammiksi malleiksi. (Eskola \& Suoranta 2000, 175-183; Tuomi \& Sarajärvi 2002, 95). Emme analysoi tekstejä diskursseina tai narratiiveina, koska vastaukset olivat pelkistettyjä ja usein luettelomaisia.

Aluksi aineisto koodattiin avoimesti ilman tarkoituksellista teoriasidonnaisuutta. Aineistossa kuitenkin esiintyi alusta lähtien tutkimuskirjallisuudessa esitettyjä huomioita mutta myös asioita, jotka eivät tulleet esiin kirjallisuudessa. Näitä kaikkia nimettiin avainsanojen avulla. Analyysityön suurin haaste oli se, että vastaukset liikkuivat käytännön toimintatapojen kuvauksista (esimerkiksi "hyödynnämme eri kanavia") paikoin hyvinkin abstrakteihin ajatuksiin (esimerkiksi "viestintä kehittyisi sellaiseen suuntaan, että viestinnän taso ja mielekkyys nousisi"). Käsitteitä oli paljon ja vastaajat antoivat niille erilaisia sisältöjä. Tämän vuoksi avainsanoja ryhmiteltiin teemoiksi ja vietiin tutkimuskysymysten mukaisiin luokkiin, kuten viestinnän strategiset tavoitteet ja viestinnän (odotettu) kontribuutio organisaatiolle tai asialle. Johtajien ja viestijöiden antamia vastauksia vertailtiin myös keskenään. Tulokset koottiin taulukoihin, joita vertailtiin keskenään ja lopuksi yhdistettiin. Aineistot käytiin lävitse useaan kertaan kolmen vuoden aikana aineiston karttuessa.

Esitämme seuraavassa osiossa tulokset jakaen ne edellä esittämämme mukaisesti viestinnän kontribuutioon organisaatiolle ja viestinnän päämääriin itsessään (Taulukko 3). Kontribuution jaamme kahteen luokkaan: tavoitteisiin, jotka palvelevat organisaation strategiaa ja tavoitteisiin, jotka koskevat organisaatiota itsessään. Viestintään itseensä kohdistetuilla tavoitteilla ei ole suoraan ilmaistua yhteyttä organisaatiostrategiaan. 
Taulukko 3. Viestinnän tavoitteiden jaottelua.

\begin{tabular}{|l|l|}
\hline Viestinnän kontribuutio organisaatiolle & Viestinnän päämäärät itsessään \\
\hline $\begin{array}{l}\text { Viestinnän tavoitteet, jotka palvelevat } \\
\text { organisaation strategisten tavoitteiden } \\
\text { saavuttamista }\end{array}$ & $\begin{array}{l}\text { Mitä organisaation tavoitteisiin/ } \\
\text { jatkuvuuteen suoraan liittymättömiä tehtäviä } \\
\text { tai ominaisuuksia viestinnällä odotetaan } \\
\text { olevan? } \\
\text { (Taulukko 6) } \\
\text { Miestinnän organisation strategisia tavoitteita } \\
\text { mitkä viestinnän tavoitteet palvelevat } \\
\text { organisaation strategisia tavoitteita? } \\
\text { (Taulukko 4) }\end{array}$ \\
\hline $\begin{array}{l}\text { Viestinnän tavoitteet, jotka palvelevat } \\
\text { organisaation ylläpitoa/muodostumista } \\
\text { Millä tavoin viestinnän tavoitteiden } \\
\text { ajatellaan palvelevan organisaation ylläpitoa } \\
\text { ja muodostumista? (Taulukko 5) }\end{array}$ \\
\hline
\end{tabular}

\section{Viestinnän kontribuutio palvelemassa organisaation tavoitteita}

Viestinnän tavoitteet ja kontribuutio organisaatiolle esiintyivät usein saman asian eri puolina. Tavoitteeksi asetettiin esimerkiksi verkkoviestinnän käytön lisääminen ja sen kautta saatavat säästöt/tulot tai organisaation tunnettuus tai brändi, joka vetää puoleensa asiakkaita ja hyviä työntekijöitä. Kontribuutioksi esitettiin esimerkiksi "tuottaa lisäarvoa organisaation ydinbisnekseen eli näkyy liikevaihdossa ja tuloksessa" tai "viestinnän ja markkinoinnin satsauksen on näyttävä tuloksissa". Määrälliset tulostavoitteet mainittiin vastauksissa lähes aina ensimmäisinä ja niitä perusteltiin laajimmin.

Erityisesti johtajat odottivat viestinnältä joko taloudellista tai yhteiskunnallista vaikuttavuutta ja näkivät viestinnän tulokset kontribuutioina organisaatiolle, esimerkiksi "näkyvyys tuo uusia rahoittajia ja kumppaneita". Usein mainittu tulos oli suoraan mitattavissa rahalla eli tuloilla tai säästöillä, etuina tai haittojen ehkäisynä. Johdon edustajat kytkivät poikkeuksetta viestinnän organisaation visioon tai strategiaan, esimerkiksi "viestintää ei voi irrottaa kaupunkistrategiasta, siksi meillä ei ole erillistä viestintästrategiaakaan".

Kummankin ryhmän vastauksissa esiintyi tavoitteita, joita kytkettiin välillisesti taloudelliseen tulokseen esimerkiksi yleisöjen tai sidosryhmien tietämys, ymmärrys, kiinnostuksen herääminen tai hyvä asiakaskokemus. Omien faktojen esiintuominen ja sitä kautta esimerkiksi edunvalvonnan mahdollistaminen ja asemoituminen päättäjien suhteen mainittiin usein.

Viestijät korostivat rooliaan tukemassa liiketoiminnan tavoitteiden saavuttamista, lisäarvon tuottamista organisaatiolle sekä oleellisten teemojen esiin nostamista. Vastaavasti johtajat odottivat viestijöiltä tukea strategialle. Viestijät toivat esiin myös tavoitteita, joissa kyse oli yhteisöllisyyden, kulttuurin ja yhteistoiminnan edistämisestä sekä 
hyvinvointiin vaikuttamisesta, joilla nähtiin yhteys organisaatiotason tuloksiin. Myös joissakin johtajien vastauksissa otettiin esiin tavoite käydä dialogia yhteiskunnassa ja organisaation sisällä sekä luoda jatkuvaa tilannepäivitystä muuttuvassa toimintaympäristössä. Dialogin tavoittelu ja yhteisen ymmärryksen luominen olivat usein kontribuution asemassa: omien näkemysten saamisen sidosryhmien tietoisuuteen ajateltiin palvelevan organisaation tavoitteita ja yhteiskunnallista vaikuttamista.

Viestijät korostivat myös sitoutumisen, työntekijäkokemuksen ja työnantajamaineen merkitystä rekrytoinneille kontribuutiona organisaation tavoitteiden saavuttamiseen. Luottamus, brändi, maine ja näihin verrattavat mainittiin eri termein jokaisessa vastauksessa, ja niillä nähtiin yhteys tuloksiin. Markkinoinnin merkitys ja integroituminen viestintään näkyi kummankin ryhmän vastauksissa.

Taulukko 4. Viestinnän tavoitteita, jotka kontribuoivat organisaation strategisten tavoitteiden saavuttamiseen.

\begin{tabular}{|c|c|}
\hline Viestinnän tavoitteita & Esimerkkejä tavoitteiden sanoittamisesta \\
\hline Tulos & $\begin{array}{l}\text { "Lopputavoitteena on myynnin kasvattaminen", "edistää asiakas- } \\
\text { pysyvyyttä", "vähentää onnettomuuksia", "kilpailujen yleisökeski- } \\
\text { arvojen kasvattaminen" }\end{array}$ \\
\hline Tietoisuus, tietämys, tieto & $\begin{array}{l}\text { "Tietoisuuden lisääminen toiminnastamme", "torjutaan vääriä } \\
\text { faktoja ja hyökkäyksiä", "mahdollisimman paljon faktapohjaista } \\
\text { informaatiota toiminnasta julkisuuteen" }\end{array}$ \\
\hline $\begin{array}{l}\text { Mission ja strategian ymmär- } \\
\text { rys sekä näiden toteutumisen } \\
\text { mahdollistaminen }\end{array}$ & $\begin{array}{l}\text { "Tukea strategian toteutumista", "strategian jalkautus kentälle", } \\
\text { "vaikuttaa siihen, että muutokset toteutuvat", "yhteisen ymmärryk- } \\
\text { sen kasvattaminen" }\end{array}$ \\
\hline $\begin{array}{l}\text { Tunnettuus, näkyvyys, } \\
\text { maine/brändi, julkisuuskuva, } \\
\text { työnantajamielikuva }\end{array}$ & $\begin{array}{l}\text { "Tavoitteena houkutteleva työnantajakuva", "uudet, kyvykkäät } \\
\text { rekryt", "Iajiamme koskevan narratiivin muuttaminen ja asenne- } \\
\text { ilmapiirin muuttaminen", "viestinnän vaikutus brändiarvoon" }\end{array}$ \\
\hline $\begin{array}{l}\text { Yhteiskunnallinen vaikutta- } \\
\text { minen ja edunvalvonta }\end{array}$ & $\begin{array}{l}\text { "Haluamme olla aktiivinen toimija alamme verkostoissa", "kyky } \\
\text { hallita dialogia tai ohjata sitä, vaikuttaa julkiseen keskusteluun", } \\
\text { "vaikuttaa poliittisiin päätöksiin" }\end{array}$ \\
\hline $\begin{array}{l}\text { Teemojen hallinta ja } \\
\text { riskien tunnistaminen }\end{array}$ & $\begin{array}{l}\text { "Kehitämme issues management -protokollan tunnistamaan ja mo- } \\
\text { nitoroimaan ympäristöä", "kyky reagoida tilannekuvan muuttuessa" }\end{array}$ \\
\hline $\begin{array}{l}\text { Työ- tai muun hyvinvoinnin } \\
\text { parantaminen }\end{array}$ & $\begin{array}{l}\text { "Vaikutetaan ilmapiiriin", "aktiivisuuteen kannustava yrityskult- } \\
\text { tuuri, mikä heijastuu koko toiminnan korkeana laatuna", "työ- } \\
\text { hyvinvoinnissa ja työkulttuurissa viestinnän merkitys on suuri ja } \\
\text { vaikuttavuus osoitettavissa" }\end{array}$ \\
\hline $\begin{array}{l}\text { Henkilöstön ja sidosryhmien } \\
\text { sitoutuminen ja odotusten- } \\
\text { hallinta }\end{array}$ & $\begin{array}{l}\text { "Sitouttaa henkilöstöä vision, strategian ja yhteisten arvojen toteut- } \\
\text { tamiseen", "sidosryhmien kuuntelu", "hyvä työntekijäkokemus" }\end{array}$ \\
\hline Markkinointi & $\begin{array}{l}\text { "Vaikuttaa kysyntään ja myyntiin", "uusien asiakkaiden saami- } \\
\text { nen laadukkailla ja kustannustehokkailla palveluilla", "palvelu- } \\
\text { konseptien kehittäminen yhdessä asiakkaiden kanssa" }\end{array}$ \\
\hline
\end{tabular}




\section{Viestinnän kontribuutio organisaatiolle itselleen}

Vaikka viestinnän kontribuutio pääasiassa ilmaistiin organisaation tavoittelemien tulosten kautta, se esitettiin myös organisaation itsensä näkökulmasta (Taulukko 5). Viestinnän esitettiin eri tavoin mahdollistavan organisaation toiminnan edellytysten, jatkuvuuden, oikeutuksen tai legitimiteetin, jatkuvan kehittymisen ja uusiutumisen. Vastauksissa esiintyi viestinnän kautta syntyvien tulkintojen ja sidosryhmien kuuntelun merkitys muuttuvassa toimintaympäristössä. Tähän liittyy myös riskienhallinta. Viestinnän nähtiin muodostavan "osan yritysarvoa ja sidosryhmien luottamuspääomaa".

Vaikka konstituution käsitettä ei sellaisenaan käytetty, organisaatioon itseensä liitetyt tavoitteet voidaan tulkita jossain määrin edustavan ajattelua viestinnästä organisaatiota rakentavana voimana. Aineistossa ei kuitenkaan tullut esiin viestinnän merkitystä strategian muodostamisessa vuorovaikutteisena prosessina (van Ruler 2018), vaan organisaatiostrategia tulee ikään kuin annettuna. Muutama viestijä totesi, että strategiatyössä ei hyödynnetä viestintää.

Taulukko 5. Viestinnän tavoitteita, jotka palvelevat organisaation muodostumista ja ylläpitoa.

\begin{tabular}{|l|l|}
\hline $\begin{array}{l}\text { Yhteisön jatkuvuus, } \\
\text { riskienhallinta }\end{array}$ & $\begin{array}{l}\text { "Varmistamme tuen järjestelmälle: suomalaisten tuki järjestelmälle } \\
\text { kasvaa", "vahvistamme jäsenyhdistysten toimintaedellytyksiä", } \\
\text { "viestintää arvioidaan muun maussa riskienhallinnan ja } \\
\text { turvallisuuden kautta", "kuuntelemme sidosryhmiä ja reagoimme } \\
\text { heidän odotuksiinsa" }\end{array}$ \\
\hline Toiminnan oikeutus & $\begin{array}{l}\text { "tunnettuus tulevaisuusorganisaationa vahvistuu ja roolimme } \\
\text { koetaan tärkeäksi", "tehdä toiminnastamme mahdollisimman } \\
\text { avointa ja läpinäkyvää, esittää toimintamme yhteiskunnallinen } \\
\text { vaikuttavuus, edistää alan toimintaa" }\end{array}$ \\
\hline $\begin{array}{l}\text { Kehittyminen ja } \\
\text { uusiutuminen }\end{array}$ & $\begin{array}{l}\text { "Teemme yhteistyötä: peilaamme keskinäisiä kokemuksiamme, } \\
\text { jaamme tietoa ja oppimaamme, pyrimme jatkuvasti parantamaan } \\
\text { käytäntöjämme", "kehitämme toimintamme vastuullisuutta ja } \\
\text { vuorovaikutteisuutta", "uudistamme työn muotoja ja vahvistamme } \\
\text { palvelukulttuuriamme" }\end{array}$ \\
\hline $\begin{array}{l}\text { Identiteetin rakentaminen, } \\
\text { kulttuuri, arvot }\end{array}$ & $\begin{array}{l}\text { "Sisäisen organisaatiokulttuurin vahvistaminen", "tuetaan yhtiön } \\
\text { sisäistä kulttuurinmuutosta ketteräksi ja rohkeaksi toimijaksi", } \\
\text { "vahvistaa identiteettiämme Suomen turvallisuusalan toimijoiden } \\
\text { yhteistyön toteuttajana ja varmistajana" }\end{array}$ \\
\hline
\end{tabular}

\section{Viestinnän itsensä tavoitteita}

Aineistossa esitettiin tavoitteita, joita ei kuvattu kontribuutiona tai muutenkaan suorassa yhteydessä organisaation tavoitteisiin (Taulukko 6). Tällaisia olivat viestinnän omat tavoitteet, toimintatavat, kehityksen suunnat tai laatutavoitteet. Laatua kuvattiin erilaisin adjektiivein, kuten esimerkiksi että viestintä on, tai sen tulee olla avointa, 
rohkeaa, selkeää tai ymmärrettävää. Myös keskustelufoorumien tarjoaminen ja kansalaiskeskustelun mahdollistaminen sekä oma läsnäolo julkisuudessa olivat käsitettävissä viestinnän omina tavoitteina ilman selkeästi ilmaistua kytköstä organisaation tavoitteisin. Viestintään itseensä kohdistuvia tavoitteita liitettiin myös organisaatiossa työskentelyyn ja sen kehittämiseen. Tämä ilmeni korostamalla ihmisten vaikutusmahdollisuuksia, vuorovaikutuksen ja dialogin käytäntöjen luomista, yhteisöllisyyden ja kulttuurin vahvistamista, osallisuuden kokemusta ja ihmisten voimaantumista. Näkyvyys, tunnettuus, brändi ja maine määriteltiin myös itseisarvoiksi ilman suoraa kytköstä organisaation tavoitteisiin. Hienoinen yllätys oli, että viestinnän rakenteiden ja kanavien ylläpitäminen tuli esiin vain kahdessa vastauksessa.

Taulukko 6. Viestinnän itsensä päämääriä.

\begin{tabular}{|l|l|}
\hline $\begin{array}{l}\text { Yhteisöllisyys, } \\
\text { arvot, kulttuuri }\end{array}$ & $\begin{array}{l}\text { "Olemme vuorovaikutteinen työyhteisö, jossa arvostamme yhteistä } \\
\text { tekemistämme, kannustamme toisiamme ja tiedostamme selkeästi yhteiset } \\
\text { tavoitteemme", "sisäinen viihtyvyys", "yhteisen ymmärryksen luominen", } \\
\text { "avoin viestintäkulttuuri" }\end{array}$ \\
\hline $\begin{array}{l}\text { Kansalaiskeskustelu } \\
\text { ja vaikuttaminen }\end{array}$ & $\begin{array}{l}\text { "Tarjoamme foorumin dialogille", "olemme aloitteellinen keskustelija } \\
\text { yhteiskunnassa", "olemme aktiivinen someviestijä", "järjestön tärkeimmät } \\
\text { kohderyhmät tietävät mitä mieltä järjestö on" }\end{array}$ \\
\hline $\begin{array}{l}\text { Sitoutuminen ja } \\
\text { työntekijäkokemus }\end{array}$ & $\begin{array}{l}\text { "Vuorovaikutuksen vahvistaminen", "osallistuminen", "aktivoimme } \\
\text { jäseniämme", "kasvatamme yleisön sitoutumista seuroihin", "sitoutuminen } \\
\text { yhteisiin tavoitteisiin tapahtuu vuorovaikutuksen ja osallistumisen kautta", } \\
\text { "rakennamme positiivista työntekijäkokemusta" }\end{array}$ \\
\hline $\begin{array}{l}\text { Brändi ja maine } \\
\text { itseisarvoina }\end{array}$ & $\begin{array}{l}\text { "Meidän tunnetaan edelläkävijänä digipalveluissa", "bränditavoitteemme on } \\
\text { olla tunnettu ja luottamusta herättävä taho", "luodaan yhtiöstä mielikuvia } \\
\text { rohkeana edelläkävijänä", "positiivinen, vastuullinen yrityskuva" }\end{array}$ \\
\hline $\begin{array}{l}\text { Näkyvyys eri } \\
\text { julkisuuksissa ja } \\
\text { tunnettuus }\end{array}$ & $\begin{array}{l}\text { "näymme mediassa, ja tunnettuus kasvaa", "positiivinen näkyvyys } \\
\text { mediassa", "näkyvyyttä ansaitun median ja työntekijälähettilyyden kautta", } \\
\text { "viestintä edistää työtapaturma- ja ammattitautijärjestelmän tunnettuutta" }\end{array}$ \\
\hline $\begin{array}{l}\text { Laatukuvauksia } \\
\text { "avoimuus, rohkeus, proaktiivisuus, notkeus, responsiivisuus", "aktiivinen ja } \\
\text { monikanavainen viestintä", "konkreettista tukea organisaatiolle", "viestintääa } \\
\text { on helppo tuottaa ja vastaanottaa", "suunnitelmallisuus", "visuaalisuus", } \\
\text { "vastuullisuus" }\end{array}$ \\
\hline
\end{tabular}

Aineisto sisälsi lisäksi viittauksia viestintää määrittäviin tekijöihin eli lähtökohtiin. Tyypillisimmillään tällainen oli viittaus organisaation strategiaan, mikä tuli esiin erityisesti johdon vastauksissa. Muutamissa vastaajien organisaatioissa erillistä viestintästrategiaa ei laadita, vaan viestintää suunnitellaan ja johdetaan organisaatiostrategian pohjalta.

Organisaatiotyypistä riippuen muita lähtökohtia olivat esimerkiksi organisaation yhteiskunnallinen tehtävä, lainsäädäntö, suositukset tai määräykset. Jonkin verran vii- 
tattiin tutkimustuloksiin, joiden perusteella viestinnän tavoitteita oli määritelty. Viestijät mainitsivat poikkeuksetta viestintäympäristön muutoksista nousevat haasteet ja riskit, jotka voidaan myös käsittää tällaisiksi lähtökohdiksi.

Tämän empiirisen aineiston valossa perinteinen jaottelu sisäiseen ja ulkoiseen viestintään ei juurikaan näkynyt, vaan ne nähtiin toisiinsa linkittyneinä ja toisiinsa vaikuttavina viestinnän muotoina. Ainoat sisäiseen viestintään selkeämmin liitettävät tavoitteet kohdistuivat työhyvinvointiin ja sitoutumisen vahvistamiseen, jotka nähtiin toisaalta kontribuutiona ja toisaalta päämääränä itsessään.

\section{Tulosten yhteenveto ja arviointia}

Aineiston perusteella näyttää siltä, että organisaatioissa viestinnän tavoitteet käsitetään selkeimmin kontribuutiona organisaation tavoitteiden saavuttamiseen. Tämä kontribuutio ilmaistaan useimmiten viestinnän tulosten, mutta joskus myös organisaation itsensä näkökulmasta. Viestinnän rooli organisaation strategian muodostajana ja uusintajana ei puolestaan aineistossa tullut esiin.

Viestinnällä toisaalta käsitetään olevan myös tavoitteita, jotka eivät suoraan liity organisaation strategiaan tai sen tavoitteisiin. Osa näistä tavoitteista on esitetty viestinnän päämäärinä itsessään tai viestinnän periaatteina tai laatuvaatimuksina. Tällaiset tavoitteet voivat toisaalta yhdistyä organisaation tavoitteisiin tai tulla mielletyksi kontribuutiona organisaatiolle, vaikka aineistossa tätä ei tuotu esille.

Lisäksi aineistossa esitettiin viestintää määrittäviä lähtökohtia, jotka viittasivat organisaation strategiaan mutta myös organisaation ulkopuolelta tuleviin vaatimuksiin, esimerkiksi lainsäädäntöön. Tutkimuskirjallisuudessa viimeksi mainittuja ei kuitenkaan sisällytetä strategiseen viestintään (Zerfass ym. 2018), kuin ei myöskään viestinnän infrastruktuurin ylläpitoa. Toisaalta lähtökohtiin luettavien etiikan ja vastuullisuuden rooli ja sisältö jäivät aineistossa vähäisiksi.

Tuloksiin voi suhtautua kriittisesti ensiksikin siksi, että aineisto on suppea ja edustaa pientä näytettä viestintäammattilaisten ja heidän esimiestensä vastauksista, jotka viestijät olivat kirjoittaneet verkkoalustalle. Tämän niin sanotun teemakirjoittamisen haasteena on, että kirjoittajat eivät välttämättä malta tai muista kertoa kaikkea oleellista, eikä tutkija pääse tekemään tarkentavia kysymyksiä (Hirsjärvi \& Hurme 2008, 34-35; Laajalahti 2014, 104). Lisäksi vastaajat edustivat yrityksiä, julkisia organisaatioita, järjestöjä ja säätiöitä, joiden viestinnän lähtökohdat voivat olla hyvin erilaisia. Aineiston rajallisuuden vuoksi emme kuitenkaan erotelleet näitä toisistaan. Aineistojen luotettavuutta voidaan arvioida myös sen perusteella, että organisaatioiden edustajat ovat tottuneita tietynlaiseen strategiapuheeseen ja osaavat esittää yleisesti hyväksyttyjä argumentteja. Strategisella tasolla vastaukset voivat myös jäädä hyvin yleiselle tai ideaalille tasolle. 


\section{Johtopäätökset}

Tutkimuskysymyksemme oli, miten strateginen viestintä ja viestinnän strategisuus käsitetään: millaista kontribuutiota viestinnältä odotetaan, millaisia tavoitteita sille asetetaan, ja millä tavoin viestintä ja organisaation strategia kytkeytyvät toisiinsa.

Strateginen viestintä voidaan tutkimuskirjallisuuden perusteella nähdä organisaatiolle elintärkeänä viestintänä (strategisen viestinnän paradigma), johtamisfunktiona palvelemassa organisaatiostrategiaa (deliberatiivinen strategia, funktionalistinen viestintä) tai organisaatioita rakentavina ja strategiaa muodostavina yhteisöllisinä prosesseina (emergentti strategia, konstitutiivinen viestintä).

Vaikka emme analysoineet empiiristä aineistoa määrällisesti, analyysi antaa aihetta ajatella, että strategisuus ymmärretään organisaatioissa ensisijaisesti funktionalistiseen tapaan: organisaatiolle tuottavan (määrällisen) kontribuution kautta. Tällöin organisaatiostrategia ja viestintä linkittyvät tiiviisti toisiinsa. Tämä ajattelutapa näkyi siinä, että määrälliset tulostavoitteet tulivat esiin lähes aina ensimmäisinä ja niitä perusteltiin laajimmin. 2000-luvulla lanseerattu strategisen viestinnän 'paradigma' esiintyi empiirisessä aineistossa siten, että tulostavoitteiden rinnalle nostettiin myös vuorovaikutteisuus sidosryhmiä ja toimintaympäristöä kohtaan (Zerfass ym. 2018). Tämä tuo viestintään myös dialogin piirteitä. (Vrt. Taulukko 1.)

Kontribuutio esitettiin myös organisaation itsensä näkökulmasta, organisaation ylläpitämisen, jatkuvuuden, kehityksen ja legitimaation kautta. Tällaisen ajattelun voidaan tulkita heijastelevan konstitutiivista viestintänäkemystä, joka ilmenee esimerkiksi tavoitteina lisätä vuorovaikutusta, kuuntelua, dialogia, kuulumisen kokemuksia, hyvinvointia ja sitä kautta vahvistaa organisaation toimintaedellytyksiä.

Konstitutiivista lähestymistä voi nähdä myös viestinnän käsittämisessä itseisarvoksi, miten viestintä tuottaa yhteistä hyvää organisaatiolle ja sidosryhmille, jopa koko yhteiskunnalle. Tällöin viestinnältä vaaditaan sekä tilanteiden ennakointia että sopeutumista kulloisiinkin tilanteisiin ja olosuhteisiin, strategiaakin uhmaten (van Ruler \& Körver 2019). Toisaalta viestinnän roolia organisaatiostrategian muodostajana ja uusintajana ei aineistossa eksplisiittisesti esiintynyt.

Viestinnälle määriteltiin myös lähtökohtia, jotka on otettava huomioon ja jotka usein määrittyvät organisaation ulkopuolelta. Yllättävä havainto oli se, että tärkeäksi lähtökohdaksi helposti oletettava etiikka ja vastuullisuus eivät esiintyneet aineistossa.

Strategista viestintää kohtaan osoitetun kritiikin jaottelimme kolmeen pääsuuntaan, joissa siihen liitetään yksipuolinen oman edun tavoittelu keinoja kaihtamatta, taipumus katsoa asioita yksipuolisesti johdon näkökulmasta sekä viestinnän tutkimuksen kohdistuminen kapeasti ymmärrettyyn organisaation tavoitteiden saavuttamiseen viestinnän keinoin.

Kritiikki näyttää kohdistuvan pääosin funktionalistiseen näkemykseen viestinnästä organisaation tavoitteiden yksisilmäisenä palvelijana. Kritiikki ei pure yhtä terävästi, mikäli viestinnän tavoitteet käsitetään laajemmin kuin pelkästään organisaatiolle tuotettavana kontribuutiona: esimerkiksi kansalaisten turvallisuutena ja terveytenä, työhyvinvointina tai vastuullisuutena. Viestinnällä tapahtuva vaikuttaminen voi olla eetti- 
sesti harkittua ja tähdätä hyväksyttäviin päämääriin, eikä pelkkä viestinnän strateginen ote tee siitä eettisesti arveluttavaa tai toisaalta oikeuta viestinnän sisältöjä, keinoja ja päämääriä.

Strategia-sanan tausta on sodankäynnissä ja propagandassa (Bernays 1928), joista se on omaksuttu liikkeenjohdon käytäntöihin. Strategisen viestinnän pohjavire on yhä funktionalismissa, mutta ajattelu on kehittynyt 2010-luvulla vuorovaikutteisempaan suuntaan. Omana viestinnän paradigmanaan sitä kyseenalaistetaan esimerkiksi liian samankaltaisena muiden viestinnän alalajien kanssa, ja tutkimuksellisena lähestymistapana sitä on kritisoitu heikosta teoriapohjasta sekä tutkimusteemojen ja metodivalintojen rajoittuneisuudesta. Ongelmallisena on pidetty myös strategia-käsitteen ylimalkaisuutta kaikkena mahdollisena "hyvänä" ja "tärkeänä" ja "taitavana" (mm. Zerfass ym. 2018; Heide ym. 2018). Toisaalta strategisen viestinnän paradigman tarjoama varsin laaja määritelmä strategisesta viestinnästä kaikkena organisaatiolle elintärkeänä viestintänä ei sinänsä sulje pois mitään metodologista otetta tai tutkimuskysymystä.

Rajallisenkin empiirisen aineistomme perusteella käsitys viestinnän strategisuudesta tai viestinnän suhteesta strategiaan näyttää monimuotoisemmalta kuin mitä tutkimus ja kritiikki antavat aihetta odottaa. Vaikka managerialistinen ja funktionalistinen perinne elää, sen rinnalla näyttäytyy myös emergentti strategia-ajattelu ja konstitutiivinen viestintäkäsitys. Viestinnän tiukka kiinnittyminen organisaatiostrategiaan ei ole itsestäänselvyys. Viestinnällä nähdään olevan myös tehtäviä, jotka ovat sen päämääriä itsessään ilman selvää suhdetta organisaation strategiaan ja sen tavoitteisiin. Edelleen viestinnällä nähdään olevan myös toimintaympäristöstä nousevia haasteita, jotka voivat olla kriittisiä organisaation jatkuvuuden kannalta. Esimerkiksi refleksiivisyys sidosryhmien odotuksia ja arvomuutoksia sekä niin sanottuja hiljaisia signaaleja kohtaan saattaa tarjota viestinnälle myös sellaisia mahdollisuuksia, joita organisaatiostrategia ei tunnista mutta jotka voivat vaikuttaa riskienhallintaan ja toisaalta organisaation tulevaisuuteen.

Viestinnän ja organisaatiostrategian välinen suhde voisikin kääntyä päinvastaiseksi, jolloin viestintä määrittää organisaatiostrategiaa. Viestintä olisi tällöin sekä nykyhetkeen reagoiva että tulevaisuutta ennakoiva toiminto, joka voi muokata myös organisaatiostrategiaa ja organisaation olemassaolon ehtoja.

Aineisto antaa aihetta jatkotutkimukselle, joka laajentaisi ja syventäisi ymmärrystä strategisesta viestinnästä. Osin samoja tutkimuskysymyksiä olisi tarpeen tarkastella laajemmalla aineistolla, johon tulisi sisällyttää myös organisaation jäseniä ja joka mahdollistaisi erilaisten organisaatioiden tarkastelun. Aineisto voisi sisältää myös organisaatioiden operatiivisia dokumentteja sekä kyselyjä konkreettisista viestinnän keinoista ja tavoitteista organisaation arjen toiminnassa. Tällöin arvioitavaksi voisi tulla sekin, missä määrin ja millä tavoin tavoitteet vaikuttavat operatiivisella tasolla, ja miten ne eroavat erilaisissa organisaatioissa. Tässä tehtyjen viestinnän eri strategisten tavoitteiden erottelujen valossa olisi myös mahdollista tarkastella organisaatioiden viestinnän ja muun toiminnan tuloksen konkreettisia mittareita - tai niiden puutetta. Lisäksi mielenkiintoinen jatkotutkimusaihe olisi strategisen viestinnän kytkeytyminen organisaation johtamiseen. 


\section{Viitteet}

1. Sytykkeenä akateemisen keskustelun viriämiseen voidaan pitää International Journal of Strategic Communication -lehden perustamisen myötä laadittua määritelmää ja kunnianhimoa rakentua omaksi viestinnän tutkimuksen paradigmakseen (Hallahan ym. 2007).

2. Strategisen viestinnän osa-alueiksi nimettiin aluksi esimiesviestintä, markkinointiviestintä, public relations, tekninen viestintä, poliittinen viestintä ja sosiaalisen markkinoinnin kampanjat (Hallahan ym. 2007). Myöhemmin siihen on sisällytetty muun muassa verkostolähtöinen kriisiviestintä, vastuullisuusviestintä, sosiaalinen media, työyhteisöviestintä ja johdon viestintä sekä yhteiskuntaja sidosryhmäsuhteet ( $O^{\prime}$ Connor \& Shumate 2018), julkisuusdiplomatia ja terveysviestintä (Zerfass ym. 2018).

3. Organisaatiolla tarkoitetaan laajasti yrityksiä, yhteisöjä, viranomaisia, järjestöjä, poliittisia ja kansalaisliikkeitä, projekteja ja kampanjoita ja tunnettuja julkisia toimijoita, kuten esimerkiksi poliitikkoja tai julkisuuden henkilöitä (Zerfass ym. 2018).

4. Osallistujien yksityisyyden vuoksi emme julkista tarkempia tietoja kurssipaikoista emmekä ajankohdista.

\section{Kirjallisuus}

Alasuutari, Pertti (2001). Johdatus yhteiskuntatutkimukseen. Helsinki: Gaudeamus.

Alasuutari, Pertti (1999). Johdatus laadulliseen tutkimukseen. Tampere: Vastapaino.

Alvesson, Mats \& Sveningsson, Stefan (2011). Management in the solution: Now what was the problem? On the fragile basis for managerialism. Scandinavian Journal of Management 27:4, 349-361. https://doi.org/10.1016/j.scaman.2011.08.002

Ansoff, H. Igor (1965). Corporate Strategy. New York: McGraw-Hill.

Apo, Satu (1995). Naisen väki: tutkimuksia suomalaisten kansanomaisesta kulttuurista ja ajattelusta. Helsinki: Hanki ja jää.

Asunta, Laura \& Mikkola, Leena (2019). Osallisuuden mahdollisuus ja haaste asiakasraatitoiminnassa. Teoksessa: Luoma-aho, Vilma \& Pekkala, Kaisa (toim.). ProComma Academic: Osallistava viestintä. Helsinki: ProCom.

Barge, Kevin \& Little, Martin (2002). Dialogical wisdom, communicative practice, and organizational life. Communication Theory 12:4, 375-397. https://doi.org/10.1111/j.1468-2885.2002.tboo275.x

Bentele, Günter \& Nothhaft, Howard (2010). Strategic Communication and a public sphere from a European perspective. International Journal of Strategic Communication, 4:2, 93-116. https://doi.org/10.1080/15531181003701954

Bernays, Edward (1928). Propaganda. New York: Horace Liveright.

Bernays, Edward (1955). The Engineering of Consent. Oklahoma: University of Oklahoma Press.

Bigler, William (2004). The new science of strategy execution. How established firms become fast, sleek wealth creators. Westport, CT: Praeger. https://doi.org/10.1108/10878570110695561

Botan, Carl (2006). Grand strategy, strategy and tactics in public relations. Teoksessa: Botan, Carl \& Hazelton, Vincent (toim.). Public Relations Theory. Mahwah NJ: Lawrence Erlbaum.

Bowen, Shannon (2016). Clarifying ethics terms in public relations from A to V, authenticity to virtue. Public Relations Review 42:4, 564-572. https://doi.org/10.1016/j.pubrev.2016.03.012

Canel, Maria-José \& Luoma-aho, Vilma (2019). Public Sector Communication: Closing Gaps between Citizens and Public Organizations. Wiley Blackwell: New York. https://doi.org/10.1002/9781119135630

Carroll, Craig (2013). The future of communication research in corporate reputation studies. Teoksessa: Carroll, Craig (toim.). The Handbook of Communication and Corporate Reputation. Oxford, UK: Blackwell Publishing Ltd. https://doi.org/10.1002/9781118335529.ch46

Christensen, Marit (2014). Communication as a Strategic Tool in Change Processes. International Journal of Business Communication 51:4, 359-385. https://doi.org/10.1177/2329488414525442

Cooren, François; Kuhn, Timothy; Cornelissen, Joep \& Clark, Timothy (2011). Communication, organizing and organization: An overview and introduction to the special issue. Organization Studies 32:9, 1149-1170. https://doi.org/10.1177/0170840611410836

Cornelissen, Joep (2014). Corporate Communication: A Guide to Theory and Practice. SAGE. 
Cornelissen, Joep; van Bekkum, Tibor \& van Ruler, Betteke (2006). Corporate communications: A practicebased theoretical conceptualization. Corporate Reputation Review 9:2, 114-133. https://doi.org/10.1057/palgrave.crr.1550015

Cornelissen, Joep (2017). Preserving theoretical divergence in management research: Why the explanatory potential of qualitative research should be harnessed rather than suppressed. Journal of Management, $54: 3,368-383$.

Deetz, Stanley (2006). Dialogue, communication theory, and the hope of making quality decisions together. Management Communication Quarterly 19:3, 368-375.

Desmidt, Sebastian \& George, Bert (2016). Do we see eye to eye? The relationship between internal communication and between-group strategic consensus: A case analysis. Management Communication Quarterly 30:1, 84-102. https://doi.org/10.1177/0893318915609406

Eskola, Jari \& Suoranta, Juha (2000). Johdatus laadulliseen tutkimukseen. Tampere: Vastapaino.

Eskola, Jari (2018). Laadullisen tutkimuksen juhannustaiat. Laadullisen tutkimuksen analyysi vaihe vaiheelta. Teoksessa: Aaltola, Juhani \& Valli, Raine (toim.). Ikkunoita tutkimusmetodeihin II. Näkökulmia aloittelevalle tutkijalle tutkimuksen teoreettisiin lähtökohtiin ja analyysimenetelmiin. Jyväskylä: PS-kustannus.

Fairhurst, Gail \& Connaughton, Stacey (2014). Leadership: A communicative perspective. Leadership 10:1, 7-35. https://doi.org/10.1177/1742715013509396

Fairhurst, Gail \& Uhl-Bien, Mary (2012). Organizational discourse analysis (ODA): Examining leadership as a relational process. The Leadership Quarterly 23:6, 1043-1062. https://doi.org/10.1016/j.leaqua.2012.10.005

Fawkes, Johanna (2007). Public relations models and persuasion ethics. Journal of Communication Management 11:4, 313-331. https://doi.org/10.1108/13632540710843922

Gregory, Anne; Invernizzi, Emanuele \& Romenti, Stefania (2013). Institutionalization, organizations and public relations: a two-sided process. Teoksessa: Sriramesh, Krisnamurthy; Zerfass, Ansgar \& Kim, Jeong-Nam (toim.). Current Trends and Emerging Topics in Public Relations and Communication Management. New York, NY: Routledge.

Gregory, Anne (2011). The state of the public relations profession in the UK: A review of the first decade of the twenty-first century. Corporate Communications: An International Journal 16:2, 89-104. https://doi.org/10.1108/13563281111141633

Grunig, James \& Hunt, Todd (1984). Managing Public Relations. New York: Holt, Rinehart and Winston.

Hallahan, Kirk; Holtzhausen, Derina; Van Ruler, Betteke; Verčič, Dejan \& Sriramesh, Krisnamurthy (2007). Defining strategic communication. International Journal of Strategic Communication 1:1, 3-35. https://doi.10.1080/15531180701285244

Hallahan, Kirk (2015). Organizational goals and communication objectives in strategic communication. Teoksessa: Holtzhausen, Derina \& Zerfass, Ansgar (toim.). The Routledge Handbook of Strategic Communication. New York: Taylor and Francis Group.

Heide, Mats; von Platen, Sara; Simonsson, Charlotte \& Falkheimer, Jesper (2018). Expanding the scope of strategic communication: Towards a holistic understanding of organizational complexity. International Journal of Strategic Communication 12:4, 452-468. https://doi.org/10.1080/1553118x.2018.1456434

Hirsjärvi, Sirkka \& Hurme, Helena (2008). Tutkija ja kirjoita. Helsinki: Tammi.

Holmström, Susanne (2005). Reframing public relations: The evolution of a reflective paradigm for organisational legitimisation. Public Relations Review 31:4, 497-504. https://doi.org/10.1016/j.pubrev.2005.08.008

Holmström, Susanne (2007). Niklas Luhmann: Contingency, risk, trust and reflection. Public Relations Review 33:3, 255-262. https://doi.org/10.1016/j.pubrev.2007.05.003

Holtzhausen, Derina (2002). Towards a post-modern research agenda for public relations. Public Relations Review 28:3, 251-264. https://doi.org/10.1016/s0363-8111(02)00131-5

Holtzhausen, Derina (2009). Postmodern Values in Public Relations. Journal of Public Relations Research 12:1, 93-114. https://doi.org/10.1207/s1532754xjprr1201_6

Holtzhausen, Derina \& Zerfass, Ansgar (2013). Strategic communication - Pillars and perspectives on an alternate paradigm. Teoksessa: Sriramesh, Krishnamurthy; Zerfass, Ansgar \& Kim, Jeong-Nam (toim.) Current Trends and Emerging Topics in Public Relations and Communication Management. New York, NY: Routledge.

Holtzhausen, Derina \& Zerfass, Ansgar (toim.) (2015). The Routledge Handbook of Strategic Communication. New York: Taylor and Francis Group. 
Hu, Ying \& Pratt, Cornelius (2017). Grounding civic engagement in strategic communication for China's public-health programs: Air quality campaigns as a case study. Public Relations Review 43:3, 461-467. https://doi.org/10.1016/j.pubrev.2017.03.002

Jarzabkowski, Paula (2004). Strategy as practices: Recursiveness, adaptation, and practices-in-use. Organization Studies 25:4, 529-56o. https://doi.org/10.1177/0170840604040675

Jarzabkowski, Paula (2005). Strategy as practice: An activity-based approach. London: Sage.

Jarzabkowski, Paula; Balogun, Julia \& Seidl, David (2007). Strategizing: the challenges of a practice perspective. Human Relations 6o:1, 5-28. https://doi.org/10.1177/0018726707075703

Johnson, Gerry; Melin, Leif \& Whittington, Richard (2003). Micro strategy and strategizing: Towards an activity-based view. Journal of Management Studies 40:1, 3-22. https://doi.org/10.1111/1467-6486.to1-2-00002

Kent, Michael \& Taylor, Maureen (2002). Toward a dialogic theory of public relations. Public Relations Review 28:1, 21-37. https://doi.org/10.1016/s0363-8111(02)o0108-x

Kuhn, Timothy \& Schoeneborn, Dennis (2015). The Pedagogy of CCO. Management Communication Quarterly 29:2, 295-301. https://doi.org/10.1016/s0363-8111(02)00108-x

Laajalahti, Anne (2014). Vuorovaikutusosaaminen ja sen kehittyminen tutkijoiden työssä. Jyväskylä Studies in Humanities 225. Jyväskylä: Jyväskylän University Printing House. http://urn.fi/URN:ISBN:978-951-39-5618-9

Lock, Irina \& Schulz-Knappe, Charlotte (2019). Credible corporate social responsibility (CSR) communication predicts legitimacy: Evidence from an experimental study. Corporate Communications: An International Journal 24:1, 2-20. https://doi.org/10.1108/ccij-07-2018-0071

Lock, Irina; Wonneberger, Anke; Verhoeven, Piet \& Hellsten, lina (2020). Back to the roots? The application of communication theories in strategic communication research. International Journal of Strategic Communication 14:1, 1-24. https://doi.org/10.1080/1553118x.2019.1666398

Lorange, Peter (1980). Corporate Planning: An Executive Viewpoint. Englewood Cliffs, NJ: Prentige Hall.

Luoma-aho, Vilma; Vos, Marita; Lappalainen, Raimo; Lämsä, Anna-Maija; Uusitalo, Outi; Maaranen, Petri \& Koski, Aleksi (2012). Added value of intangibles for organizational innovation. Human Technology. An Interdisciplinary Journal on Humans in ICT Environments 8:1, 7-23. https://doi.org/10.17011/ht/urn.201205141650

Luoma-aho, Vilma \& Olkkonen, Laura (2016). Expectation management. Teoksessa: Carroll, Craig (toim.). The SAGE Encyclopedia of Corporate Reputation. Thousand Oaks, CA: Sage, I.

Mintzberg, Henry; Ahlstrand, Bruce \& Lampel, Joseph (2009). Strategy Safari. Your complete guide through the wilds of strategic management ( $2^{\text {nd }}$ edition). Harlow, UK, FT: Prentice Hall.

Moss, Danny \& Warnaby, Gary (1998). Communications strategy? Strategy communication? Integrating different perspectives. Journal of Marketing Communications 4:3, 131-140. https://doi.org/10.1080/135272698345807

Mykkänen, Markus (2018). The Contribution of Public Relations to Organisational Decision making and Autopoesis of Organisations - The Perspective of the Luhmannian Social System Paradigm. Jyväskylä: Jyväskylä Studies in Humanities.

Nothhaft, Howard \& Schölzel, Hagen (2015). (Re)Reading Clausewitz. The strategy discourse and its implications for strategic communication. Teoksessa: Holtzhausen, Derina \& Zerfass, Ansgar (toim.). The Routledge Handbook of Strategic Communication. New York: Taylor and Francis Group.

Nothhaft, Howard (2016). A framework for strategic communication research: A call for synthesis and consilience. International Journal of Strategic Communication 10:2, 69-86. https://doi.org/10.1080/1553118x.2015.1124277

O'Connor, Amy \& Shumate, Michelle (2018). A multidimensional network approach to strategic communication. International Journal of Strategic Communication 12:4, 399-416. https://doi.org/10.1080/1553118x.2018.1452242

Olkkonen, Laura (2015). Stakeholder Expectations. Conceptual Foundations and Empirical Analysis. Jyväskylä: University of Jyväskylä.

Putnam, Linda \& Nicotera, Anne (2010). Communicative constitution of organization is a question: Critical issues for addressing it. Management Communication Quarterly 24:1, 158-165. https://doi.org/10.1177/0893318909351581

Raupp, Juliana \& Hoffjann, Olaf (2012). Understanding strategy in communication management. Journal of Communication Management 16:2, 146-161. https://doi.org/10.1108/13632541211217579 
Shockley-Zalabak, Pamela (2012). Fundamentals of Organisational Communication. Knowledge, Sensivity, Skills, Values. Boston: Allyn \& Bacon.

Schön, Donald (1983). The Reflective Practitioner: How Professionals Think in Action. New York: Basic Books. Steiner, George (1969). Top Management Planning. New York: Macmillan.

Steiner, George (1979). Strategic Planning: What Every Manager Must Know. New York: Free Press.

Steyn, Benita (2003). From strategy to corporate communication strategy: A conceptualisation. Journal of Communication Management 8:2, 168-184. https://doi.org/10.1108/13632540410807637

Steyn, Benita \& Niemann, Lynne (2014). Strategic role in enterprise strategy, governance and sustainability: A normative framework. Public Relations Review 40:2, 171-183. https://doi.org/10.1016/j.pubrev.2013.09.001

Ströh, Ursula (2007). An alternative postmodern approach to corporate communications strategy Teoksessa: Toth, Elisabeth (toim.). The Future of Excellence and Communication Management Challenges for the Next Generation. Mahwah, NJ.: Lawrence Erlbaum.

Taylor, James \& Van Every, Elizabeth (2000). The Emergent Organization: Communication as its Site and Surface. Mahvah, N.J.: Erlbaum.

Taylor, James (2009). Organizing from the bottom up? Reflections on the constitution of organization in communication. Teoksessa: Putnam, Linda \& Nicotera, Anne (toim.). Building Theories of Organization. The Constitutive Role of Organization. New York, NY: Routledge.

Torp Møberg, Simon (2015). The strategic turn in communication science: On the history and role of strategy in communication science from ancient Greece until the present day. Teoksessa: Holtzhausen, Derina \& Zerfass, Ansgar (toim.). The Routledge Handbook of Strategic Communication. New York: Taylor and Francis Group.

Tuomi, Jouni \& Sarajärvi, Anneli (2002). Laadullinen tutkimus ja sisällönanalyysi. Helsinki: Tammi.

Van Ruler, Betteke (2018). Communication theory: An underrated pillar on which strategic communication rests. International Journal of Strategic Communication 12:4, 367-381. https://doi.org/10.1080/1553118X.2018.1452240

Van Ruler, Betteke \& Körver, Frank (2019). The Communication Strategy Handbook. New York: Peter Lang.

Vásquez, Consuelo \& Schoeneborn, Dennis (2017). Communication as constitutive of organization. Teoksessa: Scott, Craig \& Lewis, Laurie (toim.). The International Encyclopedia of Organizational Communication. Hoboken, NY: Wiley.

Volk, Sophia; Berger, Karen; Zerfass, Ansgar; Bisswanger, Luisa; Fetzer, Marcus \& Koehler, Karolin (2017). How to play the game. Strategic tools for managing corporate communication. Communication Insights, Issue 3.

Werder, Kelly Page; Nothhaft, Howard; Verčič, Dejan \& Zerfass, Ansgar (2018). Strategic communication as an emerging interdisciplinary paradigm. International Journal of Strategic Communication 12:4, 333-351. https://doi.org/10.1080/1553118x.2018.1494181

Wright, Peter; Pringle, Charles \& Kroll, Mark (1992). Strategic management: text and cases. Boston Mass.: Allyn and Bacon.

Zerfass, Ansgar \& Sherzada, Muschda (2015). Corporate communications from the CEO's perspective: How top executives conceptualize and value strategic communication. Corporate Communications: An International Journal 20:3, 291-309. https://doi.org/10.1108/ccij-04-2014-0020

Zerfass, Ansgar; Verčič, Dejan; Nothhaft, Howard; Werder, Kelly Page (2018). Strategic communication: Defining the field and its contribution to research and practice. International Journal of Strategic Communication 12:4, 487-505. https://doi.org/10.1080/1553118x.2018.1493485

Zerfass, Anders \& Viertmann, Christine (2017). Creating business value through corporate communication: A theory-based framework and its practical application. Journal of Communication Management 21:1, 68-81. https://doi.org/10.1108/jcom-07-2016-0059

Åberg, Leif (2000). Viestinnän johtaminen. Helsinki: Infor. 